\title{
How does corporate social responsibility create value for consumers?
}

\author{
Todd Green and Fohn Peloza \\ Simon Fraser University, Burnaby, Canada
}

\begin{abstract}
Purpose - Research examining corporate social responsibility (CSR) demonstrates a relatively consistent level of positive support by consumers. However, CSR is poorly defined and little is known about the mechanisms by which this response occurs. This paper seeks to understand how consumers define CSR and how it can enhance the overall value proposition for consumers.

Design/methodology/approach - The value typology developed by Sheth et al. is integrated with qualitative data to enhance understanding of these value paths. Interviews were conducted with consumers through the heart of the current recession, when consumers were particularly aware of value when making purchase decisions.

Findings - The way in which CSR manifests itself determines consumer support. CSR can provide three forms of value to consumers: emotional, social, and functional. Each of these enhances or diminishes the overall value proposition for consumers. Further, value created by one form of CSR can either enhance or diminish other product attributes.

Practical implications - The current research helps managers understand how CSR can create value for consumers. As a result, managers can better position products in order to enhance overall value. Further, practitioners can match the value with which consumers identify from CSR to the dominant value driver in their product category.
\end{abstract}

Originality/value - This study highlights that CSR includes a range of activities with differential means of adding value to consumers.

Keywords Corporate social responsibility, Recession, Consumer behaviour, Qualitative research

Paper type Research paper

An executive summary for managers and executive readers can be found at the end of this article.

Consumer support for corporate social responsibility (CSR) is well established, and companies are now expected to engage in some form of CSR (Rundle-Thiele et al., 2008). Bhattacharya and Sen (2004) find that CSR contributes to a consumer's sense of well-being, and that this benefit is "rewarded" by consumers in the market. Outcomes from CSR include positive company evaluations (e.g. Brown and Dacin, 1997), higher purchase intentions (e.g. Mohr and Webb, 2005), resilience to negative information about the organization (e.g. Peloza, 2006), positive word-of-mouth (e.g. Hoeffler and Keller, 2002), and a willingness to pay higher prices by some consumers (e.g. Laroche et al., 2001).

However, research suggests that consumer responses to CSR depend on how CSR is manifested. For example, Creyer and Ross (1996) find that cause-related marketing (donating a percentage of sales) is less effective than employee volunteerism or unrestricted cash donations at countering negative news about a firm. However, Menon and Kahn (2003) find that consumers are more likely to support firms that engage in cause-related marketing when compared to firm involvement in advocacy advertising (e.g. encouraging consumers to support a given social issue with no overt

The current issue and full text archive of this journal is available at www.emeraldinsight.com/0736-3761.htm

Journal of Consumer Marketing

28/1 (2011) 48-56

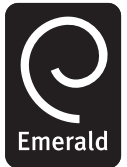

(C) Emerald Group Publishing Limited [ISSN 0736-3761]

[DOI 10.1108/07363761111101949] request to purchase from the firm). Demonstrating the lack of consistency in CSR, Peloza (2009) finds that researchers have used at least 39 unique metrics to measure CSR in empirical studies.

These equivocal results from studies examining how different forms of CSR can impact consumer behavior suggest that consumers to not perceive all forms of CSR in the same manner. Research examining CSR implicitly assumes that it is a "win-win" outcome resulting from societal support and positive consumer responses. But in order for consumers to support firms that engage in CSR, they must receive value from the exchange (i.e., the "win" for the consumer). Although no study to date has directly measured consumer value received from CSR, the studies mentioned above suggest that the value consumers receive from CSR is variable, and that their behaviors may be dependent on the value they receive.

The objective of this article is to explore when and how CSR initiatives will generate consumer support. In order to achieve this we undertake qualitative research to explore consumer experiences in the context of the 2008-2009 recession, in which consumers are likely to be highly attuned to value in their behaviors and purchases. The paper proceeds as follows. First, we examine the extant literature concerning the CSR value proposition for consumers. Next, we outline the details of interview research and present findings related to our research question. Finally, we discuss the implications for future research, marketing practitioners and policymakers.

\section{The meaning of CSR for consumers}

The CSR construct is notoriously ill-defined. Clarkson (1995) points out that despite hundreds of studies empirically examining CSR, no satisfactory and generally 
accepted definition for CSR exists. The lack of agreement on a precise definition of CSR is ultimately due to the necessary inclusion of value-laden descriptors to define the act (Wokutch and Fahey, 1986). Indeed, Murray and Vogel (1997, p. 142, emphasis added) outline consumer support for CSR as an exchange process: "The exchange is one in which the firm offers something of value - typically a social benefit or public service - to an important constituency and, in turn, anticipates receiving the approval and support" of customers.

Clarkson (1995) argues that CSR is as concept generated outside of the managerial experience, and contains normative connotations that lack clarity and specificity. He argues that values and personal judgment are needed to answer fundamental questions such as: Socially responsible to whom? Socially responsive about what?, and Social performance judged by whom and by what standards?

Consumers typically evaluate the CSR actions of a firm as they relate to their own interests. Rowley and Moldoveanu (2003, p. 206) consider CSR evaluations by stakeholders to be interest-based, and therefore will evaluate any CSR initiative relative to their own personal morals, values, and priorities. Indeed, consumers' evaluations of global firms' philanthropy varies by country and culture (Endacott, 2003). In other words, the social performance of the firm is about the evaluation of the actions, and not the actions themselves. Vogel (2005, p. 5), for example, asks: "Should Wal-Mart be considered a responsible company for providing consumers with low-priced goods or an irresponsible one for paying its employees low wages and driving out independent merchants?"

Further complicating the relationship between CSR and consumer behavior are empirical findings that employ multiple forms of CSR simultaneously. For example, Berens et al. (2005) use a two-item measure that captures both philanthropy ("supports social causes") and a measure concerning the business practices of the firm ("behaves responsibly regarding the environment"). Other examples of diffuse constructs are those taken from third party sources such as KLD or Fortune (e.g. Luo and Bhattacharya, 2009). Although such metrics provide a general view of whether CSR impacts consumer behaviour or not, they do not allow for examination of how specific firm acts can create or destroy value for consumers. Further, the form in which CSR is manifested is key to understanding how it impacts consumers since merely increasing the amount of CSR investment does not impact consumer attitudes (e.g. Barone et al., 2000).

The preceding discussion highlights a void in the extant literature examining consumer responses to CSR. Namely, a lack of examination of how CSR can create (or destroy) perceived value for consumers. Although is perhaps assumed that consumers generally respond positively to "good" acts performed by companies, their support is not equivocal. For example, a consumer may not be motivated to support McDonald's because of their work with Ronald McDonald Children's Charities, nor due to their work to green their supply chain. They may, however, be highly motivated to support the firm because of the healthy products it now offers on its menu. This example demonstrates the complexity in the consumer response to CSR, and the potential motivators behind consumer behavior.

The current research seeks to enhance our understanding of how CSR can motivate consumers. Because of the problems associated with CSR defined a priori for consumers, we undertake qualitative research in order to allow consumers to define the CSR construct and discuss how they perceive different forms to generate value. The next section details the method of our study.

\section{Method}

In order to address our research questions, we employed qualitative research because it is well suited to the goals of discovering new insights aimed at furthering the understanding of a phenomenon (Strauss and Corbin, 1990). The desire for depth of insight and relatively few a priori themes or questions suggested that depth interviews would be the most appropriate data collection technique (McCracken, 1988). Similar qualitative methods have been used by other researchers examining consumer behaviours related to CSR (e.g. Carrigan and Attalla, 2001; Essoussi and Zahaf, 2008; Mohr et al., 2001).

A total of 30 in-depth personal interviews were conducted with consumers across various metropolitan areas in North America. The interviews lasted for up to an hour and were conducted in both places of work and residence of the interviewees. The conversations were recorded and subsequently transcribed verbatim. In sum, 334 pages of interview transcripts were reviewed individually after each interview and were subsequently discussed in detail between the authors throughout the process.

A semi-structured interview guide (see the Appendix) was employed and follow-up questions were used to allow the participants to both elaborate on initial answers and to provide specific examples of purchase decisions made during the current economic conditions. The use of a semistructured interview guide allowed for the participants to discuss their purchase behavior and decision-making process in their own words and allowed the researchers to probe for deeper responses when necessary (Miller and Crabtree, 1992).

\section{Timing}

The interviews took place in 2009. This is important because discussions took place in the context of economic uncertainty and projections of hardship unrivalled since the Great Depression of the 1930s. Personal job loss (or the threat of job loss) along with a perception of continued economic hardship has significant impact on consumer decision making (Ang et al., 2000). In this new context, consumers are more focused on price, and "value is the mantra" (Johnson, 2009) that consumers are choosing to live by. The context of economic hardship and uncertainty is especially salient for decision making concerning CSR where the benefit is typically a diffuse, public good (e.g. a reduction in environmental impact) supported by individual consumers. The heightened focus on value and scrutiny on purchases exhibited by consumers in the 2008-2009 recession made it the perfect opportunity to examine how CSR motivates (or does not) consumers.

\section{Sample}

Informants were recruited from multiple cities within North America to ensure their experience was indicative of the overall economic cycle. Initial sampling was done by asking colleagues for referrals, and subsequent sampling was done through snowballing. Local unemployment rates in these 
cities were indeed indicative of national averages, ranging from 7.8 percent to 11.8 percent. Notably, the interviews were conducted through the summer of 2009, well before any leading indicators showed any expectation of an improving economy. This ensures that the sample was indeed experiencing the context of economic turmoil. Indeed, when asked how long the recession would last many respondents indicated they did not expect recovery for a period of years. Within the sample, 13.3 percent (four out of 30) of the informants were directly impacted by the recession through job loss. However, in order to maximize the generalizability of the research and achieve variation and density among consumers (Strauss and Corbin, 1990), we sought to include a sample more inclusive than just those directly impacted by the recession, and include those indirectly impacted as well.

The demographics of the sample demonstrate the diversity of the informants included in the study. In total, 14 females and 16 males were interviewed ranging in age from 22 to 57 years old, with an average age of 34 years old. The participants work in a variety of industries and vary across marital status, the number of dependents and income level. The total sample size of 30 exceeds the 12-20 informants recommended by Kuzel (1992) for "maximum variation" sampling.

\section{Method of analysis}

The interview transcripts were analyzed individually and discussed extensively between the two authors, following the iterative process suggested by Spiggle (1994). First, the interview guide was updated and altered based on themes that emerged upon the review of early transcripts and through discussion between the authors regarding how the questions were working throughout the interviewing process (Mohr et al., 2001). Furthermore, post-interview discussion with the participants resulted in both the addition of new questions and the alteration of existing questions that proved difficult for the interviewees. Each transcript was reviewed individually in order to amend the interview guide as needed and viewed as a whole when the authors identified common themes that were emerging in the interviews. Integration and coding of the transcripts resulted in the categorization of distinct themes reported by informants.

\section{Results}

We highlight a number of key findings in this section. First, we indentify that consumers do indeed scrutinize purchases more carefully during the research context. Using this context, we identify three individual forms of value CSR provides consumers. Further, we identify that these value forms are not consistently positive, nor are they independent of one another. Each of these findings is discussed in turn.

\section{Changes in purchase behavior due to the recession}

Informants discussed recent purchase decisions to illustrate the effects of the recession on their purchase behavior. Consistent with previous research examining consumer reactions to recessions (e.g. Ang et al., 2000) the majority of informants did indeed change at least some of their decisionmaking processes. These changes include spending more time thinking about purchases, buying less of certain products (common examples include entertainment such as movies, magazines, and dining out), budgeting themselves and buying necessities only (e.g. "I think of more is what is needed rather than just buying things.")

Some consumers retrenched into only purchasing necessities and putting some purchases for luxuries on hold:

My income has decreased so based on that $[\ldots]$ everything else is put on hold or you just don't even think of them; it's just a matter of getting through this.

A number of informants who were not personally impacted by the recession through job loss or reduction in income still made adjustments to their consumption patterns. These changes appear to stem from social influences and cues informants pick up from friends, acquaintances and media. For example, one informant talked about certain purchases being "embarrassing" in the recessionary context:

You can't help but think in today's times "should I spend $\$ 60$ on a shirt?"

The feeling associated with spending that much money on an item of clothing is embarrassing or it feels over the top.

This line of thinking led some informants to view the recessionary context positively, as impetus for a "purging" of creeping materialism:

The stuff that feels superficial I am purging which I think is a holistic decision. This economic conversation has really just inspired me to be more critical about everything I am buying so definitely anything that isn't substantial is being questioned.

After this initial discussion took place, the interviews turned to the subject of CSR and how decision making on this criteria has been impacted. This is discussed next.

\section{The consumer value proposition from CSR}

As the discussions with consumers moved from decision making in general toward decision making concerning CSR, consumers distinguished between different forms of CSR. Their comments suggest that consumers do not view CSR as one, overall impression of a firm. Rather, they view each initiative presented to them in relation to how it can add to the overall value proposition for a purchase. Further, for some forms of CSR, such as philanthropy, we indeed find that consumers view it as "expendable" during recessionary times as they retrench to attributes such as price and quality.

As interviews progressed, we found that consumer categorization of CSR and their subsequent perception of value corresponds to three of the value drivers identified by Sheth et al. (1991). First is emotional value (i.e., the "warm glow") that is received when a consumer makes a purchase with a social or environmental attribute. Second, social value can accrue from purchases from firms active in CSR since people make judgments about others based on the purchases they make (Yoon et al., 2006). The third source of value relevant to CSR is functional value - aspects of CSR that relate to the actual benefit the consumer receives from the product or service. These sources of value are highly predictive of consumer behavior, explaining behaviors as encompassing as product category usage, brand preferences, and interest in specific product features (Sheth et al., 1991). Each is discussed in turn.

\section{Emotional value}

When informants perceived CSR in some of the more "traditional" forms (e.g. donations to charity), the perceived value was commonly emotional. This was a salient issue for many consumers given the recessionary context. Many 


\section{Todd Green and Fohn Peloza}

informants reported a lower priority on product features delivering emotional value, particularly those related to CSR:

I think it (CSR) is just that extra bonus; I don't go to a bank that has a better charity than another[1].

Informants prioritized product performance over emotional value that they deemed as somewhat expendable given the context:

If the product measures up, yes. But I have to be responsible too. I have to be convinced that what I am getting makes sense with how long it lasts me. So you are going to be donating this much money to build a well [...] that's great, but is the item going to last?

Indeed, many of the issues that typically drive purchase intentions in CSR studies were recognized as lower in priority for the time being. Demonstrating the severity of the economic context and the discrimination between different forms of product value, some informants even expressed a lower priority on social issues normally considered nonnegotiable:

Those who seek to completely do away with any form of child labour [...] that's not really being sensitive to the current economic standard.

Informants typically discussed forms of CSR with the potential to deliver emotional value through positive initiatives by the company (e.g. donating to charity). However, activities related to CSR also provided a negative source of emotional value for many consumers. Informants in general expressed a "breaking point" beyond which negative forms of CSR. In other words, although consumers give lower priority to forms of CSR that generate emotional value, they do not give companies carte blanche when it comes to abandoning CSR. In cases of negative CSR, where consumers are generally more impacted when compared to positive CSR (Creyer and Ross, 1997), some baseline expectations still remain:

I think it's very important (to avoid irresponsible organizations) because I don't want to give my money to a company that would rather take a $\$ 100,000$ fine for pollution instead of cleaning up. There are companies like that; it's just easier for them to pay the fine than it is for them to clean up and if I know who those companies are I definitely won't buy from them.

\section{Social value}

Many of the same forms of CSR that provide emotional value for consumers also provide social value. As was the case with emotional value, social value is given a lower priority from consumers as are the forms of CSR that can provide it:

I would prefer a car that didn't scream it's a hybrid. I am not saying look at me, I am socially responsible. That's not a concern of mine.

Consumers recognize that CSR messages that promote environmental attributes, for example, can lead to enhancement in eyes of others, or be used to define oneself to the community. By being seen as someone who cares for the environment, a consumer can ensure they meet social norms and community standards that reinforce such behavior (Goldstein et al., 2008). However, informants appeared to recognize that these standards were somewhat "relaxed" in the economic context, and adjusted their CSR priorities accordingly:

If you have the choice of buying something that was more environmentally responsible or something you can actually afford and you have a whack of starving kids, you're going to make a decision pretty quick on that.

One informant compared the current trend toward purchasing with the inclusion of environmental criteria to
Volume $28 \cdot$ Number $1 \cdot 2011 \cdot 48-56$

previous "fashion trends" when environmentalism was popular, but suggests that this trend is truncated by the recession:

I remember the last wave of environmentalism, which was around the early 90 s and a whole wave of consumer yuppy-dom blew through and now it's fashionable again. So I don't know if this particular wave is another fashion trend or a more serious kick at the can.

The previous two forms of CSR value relate to some of the metrics most commonly used to define CSR such as philanthropy, social issues such as sweatshop labor, and environmental impacts both from the supply chain of the firm (e.g. pollution) and consumer use of products (e.g. vehicle emissions). Our interviews with consumers demonstrate that such forms of CSR and their associated value are given lower priorities during times of economic uncertainty and consumer retrenchment. However, interviews also suggest that these forms of CSR can create both positive and negative forms of value, and firms must ensure they meet minimum thresholds regardless of the economic climate.

Our interviews uncovered a third form of CSR described by consumers - one that is rarely considered among CSR researchers - that provides functional value to consumers.

Functional value

Although supportive of the potential for CSR, Hoeffler and Keller (2002, p. 79) acknowledge the limited connection between CSR and price and product quality, suggesting that such programs "would not be expected to have much impact on more functional, performance-related considerations." Although few researchers conceive CSR in a form that enhances the functional performance of a product (e.g. Brown and Dacin, 1997; Osterhus, 1997), the consumers in our interviews overwhelmingly include this form of CSR as part of their decision-making criteria. Sheth et al. (1991) define functional value as the capacity of an alternative to provide utilitarian or physical performance, which are the result of salient functional, utilitarian or physical attributes.

A large majority of informants (19 out of 30) suggested that functional value is the leading (and, in many cases, the sole) driver behind integrating CSR into their decision-making processes. Not surprisingly, when consumers expressed value from CSR in this form, it is highly congruent with their general move toward greater consideration for purchases around attributes such as price and product quality:

Fuel efficiency standards save the environment, but after a few years, long term, it saves you money. When these things go hand in hand, I find these are a real seller for me. That's a very competitive picture.

Many consumers report positive responses to CSR initiatives that rely on more traditional forms of CSR (e.g. recycling) but that have been crafted to incorporate functional benefits for consumers:

Even with make-up, I buy MAC and I know they recycle their packaging and they encourage people to bring it in when you are done with it. If you bring in five empty containers, they will give you a free lipstick so they encourage that [recycling].

Such initiatives are generally considered more promotional rather than CSR, but consumers do not make this distinction. Consumers include even the most traditional marketing tools such as sales promotions as part of CSR if they are positioned through social or environmental attributes. Further, these forms of CSR, and their associated value for consumers, do not appear to be subject to lower priority in times of economic 
crisis. Indeed, informants also suggested, in spite of the recession, a willingness to pay higher prices for products with functional CSR value:

I've gone more upmarket to buy things that are more expensive with the organics... so that's one example where I've sort of bucked the recessionary trends but on the other hand, I have been a little bit more price conscious with other things. Like when I bought furniture, I bought it off Craig's List, I didn't buy it new.

These findings support previous research examining consumer support for organic foods. Essoussi and Zahaf (2008) find that consumers of organics purchase these foods because they perceive them to be healthier and more nutritious, suggesting the main decision criteria for these consumers is the functional value associated with organic products. This suggests that CSR for consumers is not something that is viewed as parallel to traditional product performance. Rather, CSR and product performance can be one in the same.

Interplay of emotional, social and functional value The findings presented thus far illustrate that consumers perceive value from CSR through one of three forms emotional, social, and functional. Some CSR initiatives that rely on either emotional or social value to generate consumer response are given a lower priority for consumers, particularly during times of economic recession. Further, some forms of CSR can generate two or even three forms of value simultaneously. For example, a hybrid vehicle can provide functional value (lower operating costs), emotional value (joy in saving or environmental stewardship), and social value (meeting relevant social norms).

However, one last finding from our interviews suggests that these values are not independent on of one another. The presence of one form of CSR (and the relevant source of value) can have a direct impact - both positive or negative on other sources of value from the same product. A positive effect can occur when a CSR-related attribute creating either emotional or social value is expected to provide a higher level of functional value. For example, one informant discussed the impact on product quality from firms that use domestic labor versus overseas sweatshop labor:

Products that are more socially responsible tend to be better quality. That's not always the case, but often it is. In manufacturing, I have really noticed this for things made in Canada [...] they just seem to last longer. I don't know why that is; it could be because things are made better here.

Demonstrating the effect in the opposite direction, some informants stated that CSR in forms that provide emotional or social value can diminish perceptions of functional value for some products. This was an early criticism of some "green" products produced some years ago. Toilet paper that included a high percentage of recycled material, for example, simply was not as comfortable as the more mainstream brands. Household cleaners that used environmentallyfriendly ingredients were perceived as less effective than their traditional counterparts. However, although much of these quality differences have since been addressed (e.g. Obermiller et al., 2009), many consumers still report a quality stigma associated with some forms of CSR:

If all else is equal, then for sure, go with the more socially responsible. But it seldom seems that all else is equal. It's usually, this one is a better product, but this one is socially responsible [...] In some ways, there's a bit of a stigma there. This is fair trade coffee, which means it doesn't have to taste as good, because you're doing the right thing.
Interestingly, this effect seems to be muted for products marketed by firms that have a reputation for quality and performance:

If a more established product that went on to say "we also happen to be socially responsible" then I'd be more interested. Socially responsible is really nice, but I want a company with a track record.

The findings presented here demonstrating emotional, social and functional value, as well as the interplay between these different forms of value, are depicted in Figure 1.

\section{Discussion}

This study explored consumer support for CSR in a new context - recession combined with an uncertain economic outlook. In this context, consumers retrench to criteria such as price and quality, often at the expense of other, "higher order" criteria such as CSR. We find that consumers do indeed retrench in their decision-making processes overall, and find that consumers do indeed forsake CSR. However, this effect is equivocal and it based primarily on the perception of value in an exchange derived from conceiving CSR in different forms. Namely, CSR that provides emotional, social and/or functional value to consumers.

Emotional and social value appear to be somewhat "expendable" with consumers in a context of economic uncertainty, while CSR that provides functional value can become an even more salient criteria for decision making. Further, when consumers experience more than one form of value, often it was the functional value that was deemed to be more important when making purchase decisions and appears to have a direct influence on the perceived social and emotional value. The economic realities of the recession force consumers to prioritize and make tradeoffs, and in this context these differential effects become visible.

The first implication for future research is the need to explore consumer responses to CSR across the different forms of value consumers receive from CSR. Although much research has been done to explore consumer attitudes and behaviors toward CSR, the form of CSR has not been consistent across these studies. The majority of studies conceptualize CSR in a form that offers emotional and/or social value to consumers, such as corporate philanthropy (e.g. Mohr and Webb, 2005). More rare are studies that consider CSR as a form of functional value for consumers. These include Osterhus (1997), who examined consumer responses to energy efficient appliances, Kassarjian (1971) who examined consumer responses to various emission levels

Figure $1 \mathrm{~A}$ consumption value model of CSR effectiveness

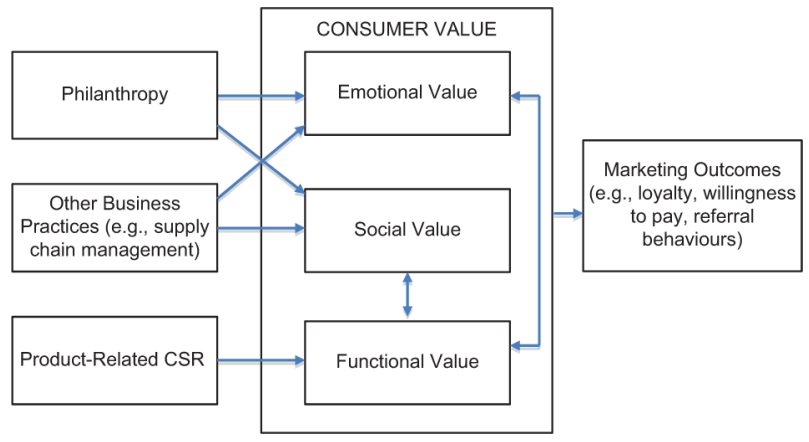


created by different blends of gasoline, and Du et al. (2008) who examined organic ingredients in yogurt. CSR in the form of organic ingredients is a particularly interesting context to examine since it contains the potential for each form of consumer value (Essoussi and Zahaf, 2008). To more fully understand how consumer support for CSR can vary, a more explicit and precise measurement of value consumers receive in exchange value is needed. Future research could examine how consumers differentiate and prioritize different forms of CSR and their associated value when choosing between products. This is particularly important in the current market context where virtually every firm has some form of CSR to promote (McKinsey, 2009).

Future research could also examine the consumer response to CSR throughout a complete economic cycle. Advertising research suggests that when firms continue to invest in advertising throughout an economic downturn, they enjoy a higher level of consumer awareness after the recession (Srinivasan et al., 2005). Does the same phenomenon hold true for CSR? Are firms that resist the temptation to cut back on CSR activity during recessionary times rewarded by consumers during subsequent periods of economic growth? Similarly, analysis of managerial practice would provide evidence of how managers see the value of CSR during recessionary times. For example, a content analysis of advertisements produced by organizations before and during the economic crisis could examine whether there has been a shift in themes from the social and emotional value of CSR to a more functional, product-related focus, or a shift in CSR overall.

\section{Managerial implications}

This research suggests that not all CSR is considered and evaluated in the same manner. Therefore, managers should scrutinize their CSR value propositions for consumers and ensure they maximize the value - particularly in productrelated forms that offer functional value for consumers. Further, consumers suggest that CSR encompasses three different sources of value and these values vary greatly depending on a number of factors, such as the economic conditions and the product category. While some consumers automatically associate CSR with providing a better quality product (e.g. clothing not produced using sweatshop labor), other consumers do not associate CSR with providing functional value and actually associate socially responsible goods with a lower quality product (e.g. fair-trade coffee). For organizations that are providing a product that is viewed as utilitarian by the marketplace, or competing in categories where product function is paramount, positioning the product solely on its CSR attributes may in fact have unintended consequences and be perceived to be of lesser quality.

A related implication from distinguishing different forms of CSR and their respective values is on the impact of CSR on consumer attitudes toward the brand. Perhaps a focus on emotional and social forms of consumer value creates a greater potential for consumer perceptions of greenwashing. Indeed, critics charge that managers are often too concerned with the public relations value from CSR (e.g. Porter and Kramer, 2002) at the expense of a focus on meaningful impact on social or environmental issues. Although emotional and social values are legitimate in consumer exchanges, the inclusion of product-related CSR and the resultant functional value is one means of ensuring marketers effectively respond to these consumer criticisms.

Another important consideration for managers is the ability for different forms of CSR value to translate to different impacts on social and environmental issues. When consumers choose products that contain CSR in the form of functional value, the widespread diffusion of that product across thousands or even millions of consumers can lead to a much greater net impact on society. For example, if Toyota undertakes a CSR initiative that is designed to reduce the emissions created by the firm by 10 percent, it can create emotional and social value for consumers. But if Toyota undertakes an initiative to produce a product that allows consumers to reduce - upon consumption - their own emissions by 10 percent, the net benefit to the environment is significantly greater. Further, when CSR is delivered through product features the consumer is repeatedly reminded of the functional CSR benefit creating a higher level of involvement and awareness of the impacts of consumption. Through the effect of positive cueing, this can lead to greater emphasis on environmental attributes in other consumption experiences for that same consumer (Cornelissen et al., 2008). Future research can explore the differential effects that different sources of consumer value can have on both environmental outcomes as well as related consumption behaviors.

Finally, for ratings agencies such as KLD, who rate firms' CSR performance, there is an opportunity for ratings agencies to take the different forms of consumer value into account in their ratings. By providing a more nuanced picture that takes into account the type of CSR - and the related form of consumer value - consumers will be better informed to make decisions in a marketplace where comparison between firms is difficult (Prothero et al., 2007). As an example, the KLD database takes product-related CSR into account to some extent (e.g. environmentally friendly products, $R \& D /$ innovation) but the consideration of these products is from the negative point of view (e.g. tobacco, military, etc.).

\section{Conclusion}

In sum, our research uses the context of a severe economic recession to provide a more nuanced understanding of consumer support for CSR. This context uncovers equivocal support for CSR, and more importantly, differential support across different types of CSR. The insights uncovered here will aid CSR-related consumer research well beyond economic recovery and guide future CSR research.

\section{Note}

1 We take comments such as this as evidence that participants were not responding in a socially desirable manner.

\section{References}

Ang, S.H., Siew, M.L. and Kotler, P. (2000), "The Asian apocalypse: crisis marketing for consumers and businesses", Long Range Planning, Vol. 33 No. 1, pp. 97-119.

Barone, M.J., Miyazaki, A.D. and Taylor, K.A. (2000), "The influence of cause-related marketing on consumer choice: does one good turn deserve another?", fournal of the Academy of Marketing Science, Vol. 28 No. 2, pp. 248-62. 
Berens, G., van Riel, C.B.M. and van Bruggen, G.H. (2005), "Corporate associations and consumer product responses: the moderating role of corporate brand dominance", Fournal of Marketing, Vol. 69 No. 3, pp. 35-48.

Bhattacharya, C.B. and Sen, S. (2004), "Doing better at doing good: when, why, and how consumers respond to corporate social initiatives", California Management Review, Vol. 47 No. 1, pp. 9-24.

Brown, T.J. and Dacin, P.A. (1997), "The company and the product: corporate associations and consumer product responses", Fournal of Marketing, Vol. 61, January, pp. 68-84.

Carrigan, M. and Attalla, A. (2001), "The myth of the ethical consumer: do ethics matter in purchase behaviour?", Fournal of Consumer Marketing, Vol. 18 No. 7, pp. 560-77.

Clarkson, M.E. (1995), "A stakeholder framework for analyzing and evaluating corporate social performance", Academy of Management Review, Vol. 20 No. 1, pp. 92-117.

Cornelissen, G., Pandelaere, M., Warlop, K. and Dewitte, S. (2008), "Positive cueing: promoting sustainable consumer behaviour by cueing common environmental behaviours as environmental", International fournal of Research in Marketing, Vol. 25 No. 1, pp. 46-55.

Creyer, E. and Ross, W.T. Jr (1996), "The impact of corporate behaviour on perceived product value", Marketing Letters, Vol. 7 No. 2, pp. 173-85.

Creyer, E. and Ross, W.T. Jr (1997), "The influence of firm behaviour on purchase intentions: do consumers really care about business ethics?", Fournal of Consumer Marketing, Vol. 14 No. 6, pp. 421-32.

Du, S., Bhattacharya, C.B. and Sen, S. (2008), "Reaping relational rewards from corporate social responsibility: the role of competitive positioning", International fournal of Research in Marketing, Vol. 24 No. 3, pp. 224-41.

Endacott, R.W.J. (2003), "Consumers and CRM: a national and global perspective", fournal of Consumer Marketing, Vol. 21 No. 3, pp. 183-9.

Essoussi, L.H. and Zahaf, M. (2008), "Decision-making process of community organic food consumers", fournal of Consumer Marketing, Vol. 25 No. 2, pp. 95-104.

Goldstein, N.J., Cialdini, R.B. and Griskevicius, V. (2008), "A room with a viewpoint: using social norms to motivate environmental conservation in hotels", fournal of Consumer Research, Vol. 35 No. 3, pp. 472-82.

Hoeffler, S. and Keller, K.L. (2002), "Building brand equity through corporate societal marketing", Fournal of Public Policy \& Marketing, Vol. 21 No. 2, pp. 78-89.

Johnson, L. (2009), "The consumer's new mantra is value", Financial Times, March 10.

Kassarjian, H.H. (1971), "Incorporating ecology into marketing strategy: the case of air pollution", fournal of Marketing, Vol. 35, July, pp. 61-5.

Kuzel, A.J. (1992), "Sampling in qualitative inquiry", in Crabtree, B.F. and Miller, W.L. (Eds), Doing Qualitative Research, Sage Publications, Newbury Park, CA, pp. 31-44.

Laroche, M., Bergeron, J. and Barbaro-Forleo, G. (2001), "Targeting consumers who are willing to pay more for environmentally friendly products", fournal of Consumer Marketing, Vol. 18 No. 6, pp. 503-20.

Luo, X. and Bhattacharya, C.B. (2009), "The debate over doing good: corporate social performance, strategic marketing levers, and firm-idiosyncratic risk", fournal of Marketing, Vol. 73 No. 6, pp. 198-213.

McCracken, G. (1988), The Long Interview, Sage Publications, Newbury Park, CA.

McKinsey (2009), "Global survey results - valuing corporate social responsibility”, available at: www.mckinseyquarterly. com/Valuing_corporate_social_responsibility_McKinsey_ Global_Survey_Results_2309 (accessed May 2, 2009).

Menon, S. and Kahn, B.E. (2003), "Corporate sponsorships of philanthropic activities: when do they impact perception of sponsor brand?", fournal of Consumer Psychology, Vol. 13 No. 3, pp. 316-27.

Miller, W.L. and Crabtree, B.F. (1992), "Primary care research: a multimethod typology and qualitative roadmap", in Crabtree, B.F. and Miller, W.L. (Eds), Doing Qualitative Research, Sage Publications, Newbury Park, CA, pp. 3-28.

Mohr, L.A. and Webb, D.J. (2005), "The effects of corporate social responsibility and price on consumer responses", Fournal of Consumer Affairs, Vol. 39 No. 1, pp. 121-47.

Mohr, L.A., Webb, D.J. and Harris, K.E. (2001), "Do customers expect companies to be socially responsible? The impact of corporate social responsibility on buying behaviour", Fournal of Consumer Affairs, Vol. 35 No. 1, pp. 45-72.

Murray, K.B. and Vogel, C.M. (1997), "Using a hierarchy-ofeffects approach to gauge the effectiveness of corporate social responsibility to generate goodwill toward the firm: financial versus nonfinancial impact”, fournal of Business Research, Vol. 38 No. 2, pp. 141-59.

Obermiller, C., Burke, C., Talbott, E. and Green, G.P. (2009), "Taste great or more fulfilling: the effect of brand reputation on consumer social responsibility advertising for fair trade coffee", Corporate Reputation Review, Vol. 12 No. 2, pp. 159-76.

Osterhus, T.L. (1997), "Pro-social consumer influence strategies: when and how do they work?", fournal of Marketing, Vol. 61, October, pp. 16-29.

Peloza, J. (2006), "Using corporate social responsibility as insurance for financial performance", California Management Review, Vol. 48 No. 2, pp. 52-72.

Peloza, J. (2009), "The challenge of measuring financial impacts from investments in corporate social performance", Fournal of Management, Vol. 35 No. 6, pp. 1518-41.

Porter, M. and Kramer, M. (2002), "The competitive advantage of corporate philanthropy", Harvard Business Review, Vol. 80 No. 12, pp. 57-68.

Prothero, A., Peattie, K. and McDonagh, P. (2007), "Communicating greener strategies: a study of on-pack communication", Business Strategy and the Environment, Vol. 6 No. 2, pp. 74-82.

Rowley, T. and Moldoveanu, M. (2003), "When will stakeholder groups act? An interest-and-identity-based model of stakeholder group mobilization", Academy of Management Review, Vol. 28 No. 2, pp. 204-19.

Rundle-Thiele, S., Ball, K. and Gillespie, M. (2008), "Raising the bar: from corporate social responsibility to corporate social performance", Fournal of Consumer Marketing, Vol. 25 No. 4, pp. 245-53.

Sheth, J.N., Newman, B.I. and Gross, B.L. (1991), "Why we buy what we buy: a theory of consumption values", fournal of Business Research, Vol. 22 No. 2, pp. 159-70. 
Spiggle, S. (1994), "Analysis and interpretation of qualitative data in consumer research", fournal of Consumer Research, Vol. 21 No. 3, pp. 491-503.

Srinivasan, R., Rangaswamy, A. and Lilien, G.L. (2005), "Turning adversity into advantage: does proactive marketing during a recession pay off?", International Fournal of Research in Marketing, Vol. 22 No. 2, pp. 109-25.

Strauss, A.L. and Corbin, J. (1990), Basics of Qualitative Research: Grounded Theory Procedures and Techniques, Sage Publications, Newbury Park, CA.

Vogel, D. (2005), The Market for Virtue, The Brookings Institute, Washington, DC.

Wokutch, R.E. and Fahey, L. (1986), "A value explicit approach for evaluating corporate social performance", Fournal of Accounting and Public Policy, Vol. 5 No. 3, pp. 191-215.

Yoon, Y., Gurhan-Canli, Z. and Bozok, B. (2006), "Drawing inferences about others on the basis of corporate associations", Fournal of the Academy of Marketing Science, Vol. 34 No. 2, pp. 167-73.

\section{Appendix. General interview guide}

\section{General questions about the recession}

- Thinking of the current economic conditions, how has it impacted your purchase decisions?

- What have you done differently in response to the current economic conditions?

- Thinking of a recent purchase (over \$100), what attributes of the product do you think made the biggest impact on your purchase decision?

- Do you consider CSR attributes i.e. pollution, charitable donations, fare trade practices, efficiency etc? Is it still important to you now?

\section{CSR-specific questions}

1 Are you able to name a few organizations that you think are socially responsible?

2 How important is it for you to purchase goods and services from organizations that are socially responsible? Why is it important to you?

3 Are you willing to pay a premium price for goods and services provided by socially responsible organizations?

- Why do you think you are willing to pay a premium or why do you not want to pay a premium?

- Has your willingness to pay a premium changed during the economic downturn?

4 How has the consideration or importance of CSR changed over the past year or two? Would you say it is more important, less important or has not changed?

\section{Corresponding author}

Todd Green can be contacted at: tdg2@sfu.ca

\section{Executive summary and implications for managers and executives}

This summary has been provided to allow managers and executives a rapid appreciation of the content of the article. Those with a particular interest in the topic covered may then read the article in toto to take advantage of the more comprehensive description of the research undertaken and its results to get the full benefit of the material present.

Corporate social responsibility (CSR) has been the focus of much research and consumers have indicated support for firms that behave in accordance with CSR expectations. This support can be in the shape of higher evaluation, greater purchase intent and positive word-of-mouth (WOM). In addition, consumers are less likely to heed negative information about the firm and display a degree of readiness to pay higher prices for its products or services.

Some studies have, however, indicated that consumer response may be determined by the form of CSR activity a company engages in. For instance, one researcher found consumers more enthusiastic about voluntary actions from employees or "unrestricted cash donations" than causerelated marketing (CRM) initiatives where the level of donation will be determined by sales made. Such examples demonstrate how consumer perception of CSR may depend on the type of activity, although findings lack any overall consistency as to which types are preferred. In return for their support, consumers seek value from an organization. Their behavior is determined by the value offered and research suggests that this value is variable.

Consumers typically measure how a company's philanthropy relates to their own values, morals, standards and priorities. There is evidence that this evaluation of CSR activities will differ by nation and culture. Given the subjective nature of the process, it is argued that consumers appraise the choice of activity rather than how it is carried out. Some firms can engage in various types of CSR activity simultaneously. Supporting a social cause while behaving responsibly towards the environment would be one example of this. In such situations, it becomes difficult to ascertain which company acts are providing consumers with the value they demand from the exchange. This is important because consumer attitudes and behavior are influenced by the type of CSR activity rather than the volume.

In the light of these apparent inconsistencies, Green and Peloza aim to improve understanding of how an organization's CSR acts can influence consumer behavior. The study involved lengthy interviews and subsequent discussions with participants in North American cities. The sample consisted of 16 males and 14 females aged between 22 and 57 and varying in terms of background. Interviews took place in 2009 when consumer decision making was significantly influenced by the prevailing economic uncertainty. It was assumed that the inevitable consumer focus on price during times of economic hardship would have repercussions for their behavior in relation to CSR.

The findings mirrored other research indicating that the recession did impact on the purchase decision making of many respondents. Behavioral changes included taking longer to decide, buying only essentials and suspending the purchase of items considered to be a luxury. Influence from such as friends, acquaintances and the media was to some extent responsible for this adjustment.

Consumer responses indicated a tendency to consider each form of CSR in its own right, instead of basing their perception of a company on its overall CSR activities. Therefore, different initiatives were examined to ascertain what value was generated to the consumer. Context was found to be significant as evidence suggested a willingness to 
dispense with certain forms of CSR because of the economic downturn.

Other researchers had identified several values which impacted most on consumer behavior. Three of these values were also significant in the current study:

1 Emotional value. This form of value is typically generated through conventional forms of CSR like charity donations. While many respondents revealed emotional value to be important, many considered it a lower priority in the current financial climate. However, it did not mean that consumers would approve of organizations that abandoned CSR. It was also discovered that certain CSR activities might generate negative emotional value for the consumer.

2 Social value. The authors point out that social value is closely linked with many of the CSR types that provide emotional value. Social value for consumers relates to how their actions are perceived in terms of the norms and expectations of their society. Using eco-friendly products is one example of behavior that can attain community approval for the individual concerned. There was again some indication of a willingness to suspend these standards during the recession. Despite this, it was perceived that firms must at least satisfy minimum requirements in order to prevent generating negative value to the consumer.

3 Functional value. It has generally not been perceived that the functional performance of a product offers much CSR value. But participants in the current study indicated that functional, utilitarian or physical product attributes did influence their behavior. To some, the increased focus on aspects like price and quality makes functional value the only CSR driver. An example cited is fuel efficiency that enhances the environment while saving money for the consumer over the longer term. Such was the importance placed on functional value, certain individuals were even prepared to pay more for certain products that incorporated this benefit.

Green and Peloza point out the potential for some CSR activities to simultaneously produce more than one value type.
The survey also suggested that values can directly impact on each other either positively or negatively. Suspect quality associated with various green products several years ago is one example of the latter effect. The positive emotional or social value would have been countered by the negative functional value. Such a contrast is less likely if the company is renowned for good quality and performance.

When considering their CSR activities, firms should account for factors like product category and economic conditions. The authors believe that efforts should be directed at maximizing the functional value offered to consumers as this may have the greatest impact. Caution is advised to managers whose products are perceived as utilitarian as some customers perceive socially responsible products as being inferior in quality. Fair trade coffee is one example. Marketing such products on CSR benefits alone therefore risks similar assumptions being made. But the inclusion of functional value in promotional campaigns will help deflect any criticisms that the firm's CSR activities are simply a publicity stunt. Greater product diffusion also becomes likelier when functional value of CSR is present; meaning a greater impact on society is possible. Another benefit of delivering CSR through product features is higher awareness among consumers of the positive effects that result from consumption.

Since research addressing CSR in terms of functional value is limited, Green and Peloza recommend further exploration of consumer response to different CSR forms. Understanding may also be increased through the creation of more effective ways of measuring the value consumers receive from an exchange. Another idea is to explore if consumers prioritize certain CSR types in their purchase decision making. It is likewise suggested that scholars could investigate CSR throughout a complete economic cycle. This might indicate that firms that maintain CSR activities during an economic downturn will be favored by consumers when prosperity returns.

(A précis of the article "How does corporate social responsibility create value for consumers?". Supplied by Marketing Consultants for Emerald.) 